\title{
Non-Financial Information versus Financial as a Key to the Stakeholder Engagement: A Higher Education Perspective
}

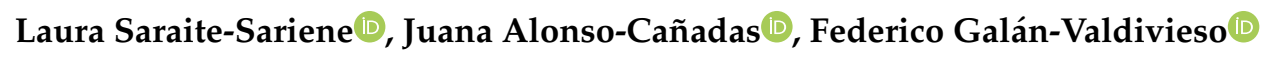 \\ and Carmen Caba-Pérez * \\ Mediterranean Research Center of Economy and Sustainable Development (CIMEDES), Department of \\ Economics and Business, University of Almería, Ctra. Sacramento s/n, La Cañada de San Urbano, \\ 04120 Almería, Spain; 1s703@ual.es (L.S.-S.); jac630@ual.es (J.A.-C.); fgalan@ual.es (F.G.-V.) \\ * Correspondence: ccaba@ual.es; Tel.: +34-950-015-857
}

Received: 9 December 2019; Accepted: 28 December 2019; Published: 31 December 2019

\begin{abstract}
In light of the increased demand for greater accountability and legitimacy, new disclosure mechanisms based on non-financial transparency have emerged. Universities cannot be left behind with respect to these social demands. In addition, continuous competition in excellence is driving higher education organizations to exhibit a greater visibility of their results, necessarily incorporating more non-financial aspects to boost stakeholder engagement. The novelty of this work lies in the analysis of the real state of non-financial vs. financial information in both public and private universities and in the exploration of their influence on stakeholder online engagement. To this end, a content analysis of the universities' web pages and Facebook profiles was conducted, and a multivariable linear regression analysis was performed. The main results show that private and larger universities that lead Webometrics for Google Scholar Citations, and those that have gradually been adopting financial reporting, are the most interested in implementing Facebook as a two-way communication strategy. It seems that stakeholders react more to financial transparency and, therefore, universities still prefer financial disclosure to improve accountability.
\end{abstract}

Keywords: sustainability accounting standards; social responsibility reporting; web 2.0 tools; accountability

\section{Introduction}

The demand for greater accountability and legitimacy has been changing in recent decades, which has implied greater information disclosure about the actions carried out by organizations [1]. The emergence of these new management models has led to traditional financial information no longer being sufficient in this respect [2]. In addition, after the last economic crisis, organizations have begun to suffer from external pressure to be more responsible within the environment in which they operate [3].

In this regard, non-financial information has been seen in recent years as an alternative to that offered in traditional financial reports, to meet the demands of different stakeholders on issues related to legitimacy and accountability [4]. Organization, corporate governance, and social responsibility information are among the most demanded issues, especially after constant corruption scandals [3]. Even so, the balance between financial and non-financial transparency could be useful, providing an informational flow of public interest that allows stakeholders to engage with the organization and participate in decision-making [5].

According to Warren et al. [6], stakeholder engagement encompasses public participation in the social affairs of organizations. Furthermore, Sashi [7] frames the concept within long-term relationships 
that are crucial for the survival of the organization. Among its main features, of note are the promotion and guidance in the process of building relationships between organizations and their stakeholders [8].

In addition, legitimacy and stakeholder theories posit that greater informative transparency helps to maintain constant communication between the organization and its stakeholders, helping the entity to inform its actions and legitimize its behavior [9,10]. According to Garde [11] and Larrán-Jorge and Andrades-Peña [12], this framework can explain the communication management of non-financial information to fulfill the responsibility of being transparent and thus achieving the commitment of all stakeholder groups.

Accountability, as a means of creating value and improving stakeholder involvement, needs to be implemented through the non-financial transparency disclosed along with financial information in both the public and private sectors $[3,13,14]$. In this regard, the literature on information disclosure basically focuses on the analysis of the non-financial information contained in the private sector's annual reports [15-17]; comparative studies in the adoption of different reports in the public sector [3]; analysis of the implementation of new integrated disclosure models [18]; and sustainability reporting [19-21] or intellectual capital disclosure $[22,23]$ in the university sector. On the other hand, there have been several studies analyzing the motivations for stakeholder engagement through social media concerning the private [24,25] and the public spheres [26-29]. However, the incorporation of non-financial and financial information in engagement behavior has been less studied, especially in the university sector.

To meet the expectations of different social and legal issues, universities must set and maintain strong and lasting relationships with their key stakeholders and seek their engagement [30]. Therefore, universities strongly need to be present on the Internet in order to reach a certain level of stakeholder engagement, which allows them to receive relevant feedback for their continuous improvement in accountability and governability [31,32]. Thus, the use of bidirectional communication models between the university and its main stakeholders is the key to engaging the latter in an effective and efficient manner [31]. In this regard, social media allows participation, open dialogue, engagement, and connectedness [33].

Therefore, the purpose of this study is to explore the current situation of non-financial versus financial information in the university sector and analyze whether this type of transparency has an effect on stakeholder engagement. Within this context, this research aims to address the following research questions:

RQ1: Do universities promote transparency initiatives toward non-financial vs. financial information? Are there significant differences between public and private institutions?

RQ2: Among the drivers of university stakeholder engagement via Facebook, to what extent does non-financial and financial information influence its levels?

The findings of this study could shed some light on the trends and gaps that should be improved to make universities' web pages a more accountable mechanism to disclose non-financial information. In addition, it can also provide fresh insights about the influencing factors in the greater use of Web 2.0 tools as channels for fostering participation and supplying online services for their different stakeholders. Moreover, from a practical standpoint, the analysis of the non-financial information and its influence on the online engagement achieved by the world's best-ranked universities could be used as a benchmark by other universities in order to enhance these open initiatives.

To achieve the aforementioned goals, this study is structured in six sections. Following this introduction, the second section provides literature related on non-financial information as a key to enhance stakeholder engagement. The third section sets the theoretical framework and the main influencing factors of online engagement. The fourth section details the methodology. The fifth section presents the results and discussion, and, finally, the main conclusions are presented. 


\section{Non-Financial Information as a Necessary Way for Transparency and Stakeholder Engagement}

For many years, the dissemination of financial information has been one of the main trends in the literature [16]. Under a strict regulatory framework in the private sector, financial information has reached a normalization and general acceptance [4], while efforts are increasingly being made to promote the dissemination of non-financial information in different countries. For instance, the European Union is taking a series of actions toward a legal standardization of non-financial information through the issuance of Directive 2014/95/EU [34]. In this sense, Dumay et al. [17] point out that European organizations are increasingly following management models that include disseminating their non-financial performance, especially considering that such legislation requires companies to include non-financial statements in their annual reports since 2018.

At a country level, different changes have been made in external reporting laws such as the legislation on guidelines for external reporting by state-owned companies in Sweden, the extension of Danish Financial Statements Act in Denmark, or the Grenelle II Act in France, among others [35]. In Spain, the Spanish Association of Accounting and Administration (AECA) has developed a framework to bring companies and their stakeholders closer to comparable, analytical, and useful non-financial information to make better decisions. In the U.K., the legislation demands that non-financial reports are to be part of the annual management report, elucidating environmental matters, employees, social matters, respect for human rights, anti-corruption, and anti-bribery matters [36]. German legislation is similar, with the only difference being that the sustainable report can be published separately, or even on the website for up to four months after the publication of the annual management report [36]. Italy has gone one step further and also requires organizations to disclose energy and water use, greenhouse gas emissions and air pollution, or social and employee-related matters including gender equality, among others [37].

In the U.S., the Sustainability Accounting Standards Board (SASB) presents a much more detailed guidance on the what, how, and where of corporate sustainability reporting [38]. Federal and state laws, at least in some situations, force organizations to disclose information related to environmental, social, and governance aspects [39]. In addition, the Securities and Exchange Commission (SEC) currently has 11 mandatory provisions for the disclosure of non-financial information in the management report, in particular the Sarbanes-Oxley Act, Pay Ratio Disclosure, SK Regulations and Securities Act Rule 408, and Exchange Act Rule 12b-20 [40,41]. The securities laws generally require that organizations disclose sufficient non-financial information to avoid confusing stakeholders; this requirement also extends to less formal non-financial reports such as sustainability [38]. From the private sphere, the securities market NASDAQ publishes a guide for the dissemination of social, environmental, and government information for companies that are listed in the Nordic and Baltic context, although it does not yet require these reports in the U.S. [42].

Apart from the main developed economies, the establishment of mandatory integrated reports in South Africa (King Code III) can also be mentioned [35]; moreover, the national organizations of Australia, together with New Zealand and Japan, are coordinating with the International Integrated Report Committee for the disclosure of non-financial information [43]. Although in Australia there is no legal requirement for sustainability reports, Australian companies are more active in disclosing their non-financial performance than China, for example, where non-financial reporting is in an initial phase $[43,44]$.

These recent regulations in the private sector have pushed the public sector to incorporate guidelines in this regard to enhance the government's transparency and legitimacy [4]. Despite recent efforts to improve public accounting, traditional financial reports do not meet the expectations of different non-professional users [3]. In this regard, the management reforms focused on accountability have only been gradually applied in the public sector [45,46]. As public administrations provide services financed through their citizens' taxes, they need to make all the transparent processes even more accountable through non-financial information $[3,4,47]$. Therefore, different non-financial information 
tools such as sustainability and integrated reporting are considered the most commonly used for greater accountability, and cover social, environmental, and economic performance [2,3,48].

Regarding non-financial information, also known as Social Responsibility Reporting [49], the EU Directive [34] has established six issues to be released in relation to environmental, social, and employee matters with respect to human rights, anti-corruption, and bribery. Along the same line, Arvidsson [15] points out that organizations need to reflect information on all intangible capitals (human, relational, organizational, environmental, and social responsibility) with the ability to create value. Orens et al. [50], in their web content study, focused on corporate governance and organization, customer value, intellectual capital, performance indicators, Research, Development and Innovation (R+D+i) and social responsibility issues. On the other hand, Biondi and Bracci [3] highlighted the importance of organizational, governance, strategy and performance, and social and environmental disclosure for public institutions. Montesinos and Brusca [4] coincided on social, environmental and governance issues in this respect. Concerning universities, Brusca et al. [18] used the framework established by the International Integrated Reporting Council to evaluate the state of integrated reporting that included organizational, governance, and strategic information, both using different financial and non-financial performance indicators.

In relation to the disclosure of financial information, the application of uniform accounting protocols has allowed greater comparability and transparency in all contexts [51]. The main aim of financial transparency is to provide reliable information about the organization so that different stakeholders such as potential investors or financing entities, among others, can make sound decisions when establishing relationships with the reporting organization [52]. These new administrative reforms for greater accountability are no longer enough just to report compliance with the rules, but the allocation and use of resources are also of special interest $[53,54]$. In this regard, the use of funds in activities to protect the environment in which the organization carries out its mission has been gaining strength $[55,56]$. These types of operations, called "green finance", strengthen the reputation of the organization and improves legitimacy vis-à-vis all affected stakeholders [57,58].

Universities, as important actors in the economy that contribute to society from different perspectives, have also been affected by such transparency requirements [59]. Moreover, the recent transformation regarding knowledge creation (and the need to share it) has also been favored by the greater openness of overall academic and research activities [60]. Thus, as fundamental organizations in society, universities generate great interest among stakeholders and need their participation and commitment to achieve their mission [61]. In recent years, universities have been adapting to a more competitive environment and have fostered collaboration with the other economic agents [18]. Value creation for stakeholders has become the key issue in university management, thus increasing the disclosure of non-financial information [62]. In addition, greater transparency on intangible capital has become a requirement for greater accountability, according to the new management models [63]. In this regard, Ramirez and Gordillo [64] provide a model to measure intellectual capital in the university industry. Although this non-financial aspect prevails in business management, an increasing number of non-for-profit organizations including universities are showing greater interest in adopting a non-financial approach [24].

Despite the importance of new accountability mechanisms, and according to the Global Reporting Initiative (GRI), it has been found that, in the last five years, only 105 universities worldwide have published sustainability reports to assess their economic, social, and environmental performance in the GRI database. It is worth mentioning that only 68 have followed the GRI standards and that most of them are private.

Nevertheless, due to the demands of greater transparency and accountability, and the continuous competition in excellence, universities are being forced to foster greater visibility of their results, necessarily incorporating a higher number of non-financial aspects [64]. In this sense, this paper seeks to examine the current situation in the use of transparency mechanisms for greater organizational legitimacy and stakeholder commitment. 


\section{Explanatory Factors of Stakeholder Engagement}

Organizational non-financial and financial transparency and online engagement, together with an adequate social media management, represents an effective strategy to meet key stakeholder demands and to ensure a greater commitment for the benefits of legitimacy such as stability, survival, and stakeholder loyalty [65]. In this sense, Garde [11] and Reverte [66] point out that stakeholder and legitimacy theories, among others, represent an adequate framework on how non-financial information helps to satisfy the informative expectations of the stakeholders for greater organizational legitimacy. Additionally, Larrán-Jorge and Andrades-Peña [12] argue that stakeholder theory is the best suitable theory to explain the greater visibility of universities in terms of economic, social, and environmental performance. Moreover, the presence of universities in social media provides stakeholders with a channel through which to access the organization's information, and potentially, the ability to create dialog between them and the organization [67]. Considering that university managers implementing accountability mechanisms based on non-financial information need to meet the opinions of different stakeholders in order to open the participation process in management issues, this paper considered the stakeholder and legitimacy theories.

According to stakeholder theory [68], organizations should achieve their goals with consideration of their different stakeholders. In this regard, all entities should inform their stakeholders about the activities carried out and, in doing so, achieve loyalty, which in turn serves as a background for long term social relationships [69]. Accordingly, one of the key elements that universities can use in managing relationships with their stakeholders is to establish more direct and fluid channels of communication. Social media can facilitate the participation of all stakeholders and thus contribute to effective accountability [26,67].

Legitimacy theory poses that there is a "social contract" between the firm and society, subjectively created as it heavily depends on the perception that the audience holds about the organization [54]. Likewise, the author argues that "legitimacy management rests heavily on communication" [54] (p. 586). Therefore, organizations are interested in strategies that can boost the level of interactions between the firm and society and use information and communication technologies (ICTs) in order to ensure the stakeholders' comprehensibility and approval of the activities they carry out [70]. In line with the above, universities as fundamental institutions of society must maintain strong and lasting relationships with their principal stakeholders.

Based on these theories and previous literature, several factors have been traditionally considered: organizational size [28,71]; reputation [72]; location [73,74]; transparency and online activity [29], or communication and public participation [75]. This paper examines the most suitable factors related to the private and public sector as well as other aspects that are specific to the university sector: "Funding", "Size", "Transparency", and "Reputation".

\subsection{Funding}

The main difference between public and private universities is the nature of the funds [76]. Public universities depend on public administration funding, while private universities, generally controlled by non-governmental organizations, are financed through donors, tuition, private funds, and, to a lesser extent, public funds [77]. Under the legitimacy theory approach, private organizations can sometimes carry out their objectives under social acceptance, but not necessarily meet the expectations of stakeholders [76]. In this sense, they need effective accountability and communication with their stakeholders to influence their perceptions [78]. Therefore, to overcome the barriers that hinder communication with all groups of society, the organizations need two-way channels such as social media, which improves trust, transparency, and deals with globalization issues [79,80]. With regard to private universities, stakeholder engagement needs to be enhanced by disclosing information about the destination of the funds, and to what extent the investment affects students, research, and social commitment [77]. 
Consequently, this study argues that private universities could be more motivated than public universities in using social media to seek stakeholder approval, since the trust of donors and students can be very volatile, and thus private universities could be under increasing pressure to meet the accountability expectations of their current and potential stakeholders. Taking this into consideration, the first hypothesis is the following:

Hypothesis 1 (H1). Private funding has a positive influence on stakeholder online engagement level in universities.

\subsection{Size}

Organizational size is a key factor that has been used in previous research on social and economic practices [81]. Larger organizations are generally exposed to greater public scrutiny as they have greater visibility and suffer from more pressure from the environment in which they operate [66]. According to legitimacy theory, larger universities would be more interested in offering content with relevant and demanded information in order to improve their reputation, image, and the commitment of their stakeholders [31]. In this regard, social media could be a channel to help develop the correct strategies of open government [82]. Accordingly, Haro et al. [28] found a positive relationship between the size of the institution and stakeholder engagement via Facebook. Thus, it can be assumed that the larger the size of the university, the greater the need for interaction. Taking into consideration that larger universities are more likely to use social media, the following hypothesis is proposed:

Hypothesis 2 (H2). Size has a positive influence on stakeholder online engagement level in universities.

\subsection{Transparency}

As Ackerman and Sandoval-Ballesteros [83] noted, both public engagement and transparency improve trust in decision making through the generation of ideas and resources. Moreover, AECA frames engagement within global organizational transparency [5]. In this sense, more transparent organizations generate greater confidence, facilitating the most effective dialogue, which in turn encourages greater stakeholder engagement [67].

As Flores et al. [5] and Eccles et al. [84] point out, the dissemination of non-financial and financial information allows the organization to reach greater stakeholder engagement, reducing information asymmetries to participate in decision making. In the same line, Michelon [10] found that organizations with greater media exposure and a strong commitment to their stakeholders are the most prominent to disseminate a greater amount of non-financial information to their stakeholders. In this sense, the relationships created between the organization and its stakeholders are based on trust, and therefore create greater engagement toward the organization in response to that greater non-financial transparency. In contrast, Galán-Valdivieso et al. [85] obtained mixed results, arguing that revealing certain non-financial information increased stakeholder engagement. However, they found that reports on social responsibility and profitability information had negative effects on stakeholder participation.

Universities, as institutions of public interest, cannot be left behind in this matter [86]. Based on stakeholder theory applied in the university sector, Cerrillo [87] stated that it was not enough to offer a large quantity of information to satisfy the stakeholders' demands, but also to pay attention to the quality of the content and the ease of access through different mechanisms. In this regard, social media offers an opportunity to increase dialogical communication for greater user engagement $[8,88,89]$. Consequently, and in line with the objectives of this study, the following hypotheses are posited:

Hypothesis 3 (H3). Non-financial information has a positive influence on stakeholder online engagement level in universities. 
Hypothesis 4 (H4). Financial information has a positive influence on stakeholder online engagement level in universities.

\subsection{Reputation}

According to stakeholder theory, relationships based on confidence determine the long-term organizational outcomes and reputation [90]. In the last decade, technological advances have allowed organizations to dramatically change their way of communicating with their stakeholders in order to enhance trust and adapt to the demands of dialogical interactions [91]. Using social media to disseminate information about their activities and thus strengthening stakeholder relationships and engagement has been perceived as a benefit to the organizational reputation that in turn could help increase organizational outcomes [91,92]. In this sense, it could be understood that organizations will take more proactive actions in social media to improve their reputation, especially by initiating conversations with stakeholders to strengthen confidence.

Within the context of universities, research outcomes are one of the prestige indicators of greatest social interest [93]. Such reputation or prestige is achieved by improving different organizational systems in order to position the university in the different university rankings [94], which measure the excellence of research and academic issues [95]. In fact, these results affect different groups: students, both current and future, in choosing their studies; employees in the hiring process; and even the process of raising funds and undertaking reforms [96]. Consequently, it would be reasonable to expect that those leading universities would be the most incentivized to use social media as a channel to inform their stakeholders of the entity's excellence in research, and thus promote greater online interactions. Therefore, the following hypothesis is shown:

Hypothesis 5 (H5). Reputation has a positive influence on stakeholder online engagement level in universities.

\section{Methodology}

\subsection{Descriptive-Comparative Analysis}

To answer the first research question, the descriptive analysis was structured in two phases. First, the Global Transparency Index (GTI) was used based on Saraite et al. [97]. The data were collected manually by two researchers working independently in order to update the information to the present (2019). There was an initial meeting to clearly set out the strategy for each indicator and then the results were reviewed at the end to solve any discrepancies and to overcome any possible bias.

Second, the process of the segregation of non-financial and financial information was performed based on previous literature: non-financial information was divided into three dimensions, "Organization and Governance", "Management Information and Quality", and "Information on Social Responsibility" $[1,6,11,15,50,66,98,99]$ and the financial information was extracted from the index [100-102]. The considered items are identified in Table 1.

Table 1. Non-financial and financial information items.

\begin{tabular}{ll}
\hline & NON-FINANCIAL INFORMATION \\
\hline 1 & ORGANIZATION AND GOVERNANCE \\
2 & Organization chart (structure) \\
3 & Administrative offices and functions \\
4 & Directory \\
5 & Chancellor schedule \\
6 & Details about bibliography of Chancellor and Vice Chancellors \\
7 & Details about remuneration \\
8 & Minutes of agreements made by Governing Council of the University \\
9 & Regulations passed \\
\hline
\end{tabular}


Table 1. Cont.

\begin{tabular}{cc}
\hline & NON-FINANCIAL INFORMATION \\
\hline 10 & MANAGEMENT INFORMATION AND QUALITY \\
11 & Approved strategic plan \\
12 & Execution of strategic plan \\
13 & Publication of invitations to tender for purchase of goods and services \\
14 & Resolution of works and services \\
15 & List of suppliers \\
16 & Effectiveness and efficiency indicators \\
& Human Capital \\
17 & INFORMATION ON SOCIAL RESPOSIBILITY \\
18 & Economic impact \\
19 & Social impact \\
& Environmental impact \\
1 & FINANCIAL INFORMATION \\
2 & Approved budget \\
3 & Budgets modification \\
4 & Expenses \\
5 & Revenues \\
6 & Budget indicators \\
7 & Treasury activity \\
8 & Outstanding debt \\
9 & Debt variation \\
10 & Noncurrent assets \\
& Variation of noncurrent assets
\end{tabular}

Source: Own compilation.

In addition, comparative analysis was carried out in order to know the state of non-financial vs. financial information disclosure. To this end, the " $\mathrm{t}$ " test was applied to find whether there were significant differences between public and private universities in terms of transparency in diffusing non-financial and financial data, following previous research methodology on online information disclosure $[103,104]$.

\subsection{Explanatory Analysis}

The explanatory power of the five independent factors on universities' stakeholder engagement (see Table 2) was analyzed by applying multiple regression, an appropriate technique to identify whether certain independent variables have predictive power or are explicative for a continuous dependent variable [105], particularly if certain organizational factors have explicative power on the level of stakeholder online engagement attained by universities. The dependent variable "Engagement" (ENG) was measured as shown in Table 3.

Table 2. Independent variables.

\begin{tabular}{lll}
\hline FACTOR & MEASUREMENT & EXPECTED RELATIONSHIP \\
\hline Funding (FUND) & $\begin{array}{l}\text { Dummy variable, noting 0 in the case of public universities and 1 for } \\
\text { private ones [1]. }\end{array}$ & H1+ \\
\hline Size (SIZE) & No. of students [106]. & H2+ \\
\hline Non-Financial Information (NFI) & $\begin{array}{l}\text { Non-Financial Information index based on Global Transparency Index } \\
\text { developed by Saraite-Sariene et al. [97] and updated up to 2019. }\end{array}$ & H3+ \\
\hline Financial Information (FI) & $\begin{array}{l}\text { Financial Information Index based on Global Transparency index } \\
\text { developed by Saraite-Sariene et al. [97] and updated up to 2019. }\end{array}$ & H4+ \\
\hline Reputation (REP) & $\begin{array}{l}\text { The position in the Ranking Web (Webometrics) by citations in top } \\
\text { Google Scholar profiles (2019). }\end{array}$ & H5+ \\
\hline
\end{tabular}

Source: Own compilation. + positive relation expected. 
Table 3. Metrics of stakeholder engagement.

\begin{tabular}{ccll}
\hline & SIGN & \multicolumn{1}{c}{ FORMULA } & \multicolumn{1}{c}{ MEASURES } \\
\hline \multirow{3}{*}{ POPULARITY } & P1 & Posts with likes/total posts & Percentage of total posts liked \\
& P2 & Total likes/total posts & Average number of likes per post \\
& P3 & (P2/number of fans $) \times 1000$ & Popularity of messages among fans \\
\hline \multirow{3}{*}{ COMMITMENT } & C1 & Posts with comments/total posts & \% of total posts that have been commented \\
& C3 & Total comments/total posts & Average number of comments per post \\
& (C2/number of fans) $\times 1000$ & Commitment of fans \\
\hline \multirow{3}{*}{ VIRALITY } & V1 & Posts with shares/total posts & \% of the total posts that have been shared \\
& V2 & Total shares/total posts & Average number of shares per post \\
& V3 & (V2/number of fans) $\times 1000$ & Virality of messages among fans \\
\hline \multicolumn{5}{c}{ ENGAGEMENT (ENG) $=$ POPULARITY (P3) + COMMITMENT (C3) + VIRALITY (V3) } \\
\hline \multicolumn{4}{c}{ Source: [67]. }
\end{tabular}

Taking all of this into consideration, the proposed model for "Engagement" is the following:

$$
\mathrm{ENG}_{\mathrm{i}}=(\text { Constant })+\beta_{1} \cdot \mathrm{FUND}_{\mathrm{i}}+\beta_{2} \cdot \mathrm{SIZE}_{\mathrm{i}}+\beta_{3} \cdot \mathrm{NFI}_{\mathrm{i}}+\beta_{4} \cdot \mathrm{FI}_{\mathrm{i}}+\beta_{5} \cdot \mathrm{REP}_{\mathrm{i}}+\mu_{\mathrm{i}},
$$

where ENG is the dependent variable; $\beta$ is the parameters to be estimated; FUND, SIZE, NFI, FI, and REP are the different independent variables; $\mu$ is the classic disturbance term; and i refers to each of the universities considered.

\subsection{Study Sample and Data Collection}

This research analyzes the official Facebook profiles and web pages of the best-ranked universities by the Academic Ranking of World Universities (ARWU 2018). This ranking takes into consideration several indicators of academic performance and excellence in research including alumni and staff winning Nobel Prizes and Fields Medals, highly cited researchers, papers published in Nature and Science, papers indexed in major citation indices, and per capita academic performance of an institution. Due to its solid and transparent methodology, based on a detailed study of more than 2000 universities around the world, ARWU is considered the most influential ranking system $[104,107,108]$.

On one hand, the profile of each Facebook page was found in the web pages of the universities and this link was used to obtain the name of the Facebook profile. In particular, the data were compiled using ad hoc software developed for this research, both for data extraction and for its subsequent aggregation. Specifically, the software developed was responsible for retrieving data available from Facebook pages using queries based on Power Query M language to Facebook Graph Application Programming Interface. Consequently, due to the inability to access the necessary data, the final sample consisted of 71 universities. It is worth mentioning that $90 \%$ of the sample is represented by European and U.S. universities, and the rest belong to other areas (for example, Singapore, China, and Israel).

On the other hand, the content analysis for non-financial and financial information was carried out through the official web pages of these 71 universities. The period of analysis was October 2019.

\section{Results and Discussion}

\subsection{Descriptive Analysis}

In general terms, it has been possible to identify that universities still prefer financial information to meet the demands of their stakeholders for accountability and transparency (Figure 1). 


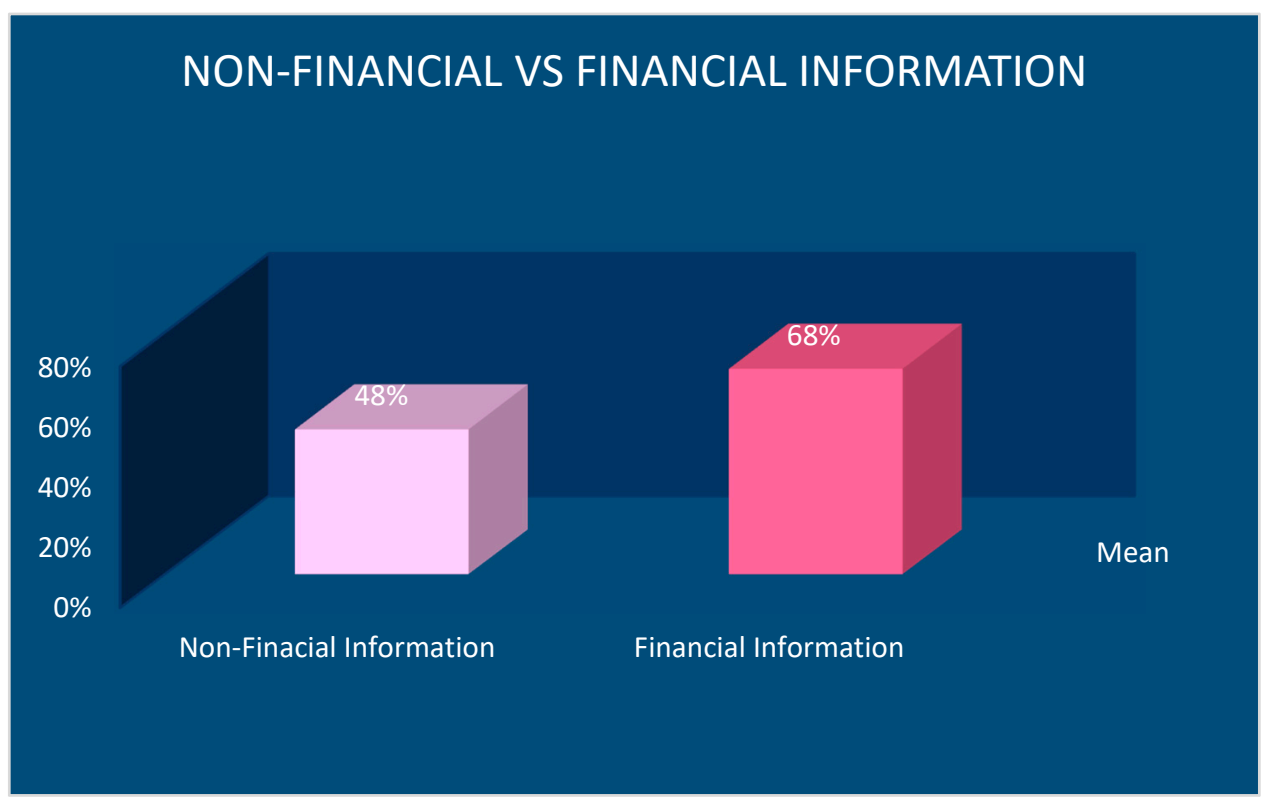

Figure 1. Non-financial vs. financial information. Source: Own compilation.

The main results of the descriptive analysis showed that there were differences in the transparency practices on non-financial and financial information in both sectors (Table 4). However, the difference in the non-financial information was not statistically significant. Private universities presented higher levels of e-information, both non-financial and financial. These results are in line with Biondi and Bracci [3] and Arvidsson [15], who confirmed an increase in the disclosure of non-financial information in the private sector, due to both the legislative framework and the demands by stakeholders, to compensate informational deficiencies in the financial statements. However, these findings are contrary to previous literature in the public sphere, pointing out that public organizations, being financed with public funds, are under greater public scrutiny and, therefore, are more concerned with adopting information disclosing initiatives as soon as possible for the satisfaction of society $[109,110]$. Moreover, the results diverge from those obtained by Liguori et al. [46], who found that public managers were more interested in disclosing non-financial than financial information.

Table 4. Descriptive statistics.

\begin{tabular}{lccccccccc}
\hline \multicolumn{1}{c}{ Funding } & \multicolumn{4}{c}{ PUBLIC } & \multicolumn{5}{c}{ PRIVATE } \\
\cline { 1 - 8 } \multicolumn{1}{c}{ Variable } & Min & Max & Mean & SD & Min & Max & Mean & SD & \\
\hline Non-Financial Information & 0.000 & 0.789 & 0.474 & 0.161 & 0.263 & 0.842 & 0.532 & 0.130 & -1.436 \\
Financial Information & 0.091 & 0.909 & 0.629 & 0.342 & 0.091 & 1.000 & 0.809 & 0.224 & $-2.171^{* *}$ \\
\hline
\end{tabular}

Notes: ** $p<0.05$. Source: Own compilation.

With regard to the type of information, it could be first highlighted that financial information was the more frequently disclosed data in both sectors (Figure 2). It can also be observed in Table 1 that the universities did not give the same importance to all non-financial aspects. In particular, there was a high level of interest in more general aspects about organization and governance. Hence, it seems that universities understand the relevance of disclosing organizational non-financial information, but they still do not value the importance of responding to the growing demand for specific information regarding social responsibility, with information related to management being the most undervalued. Partially, these results are related with those obtained by Arvidsson [15] for the private sector, showing that the non-financial information on which the disclosure is centered is general information about the organization and governance, with the information on social responsibility less released. 


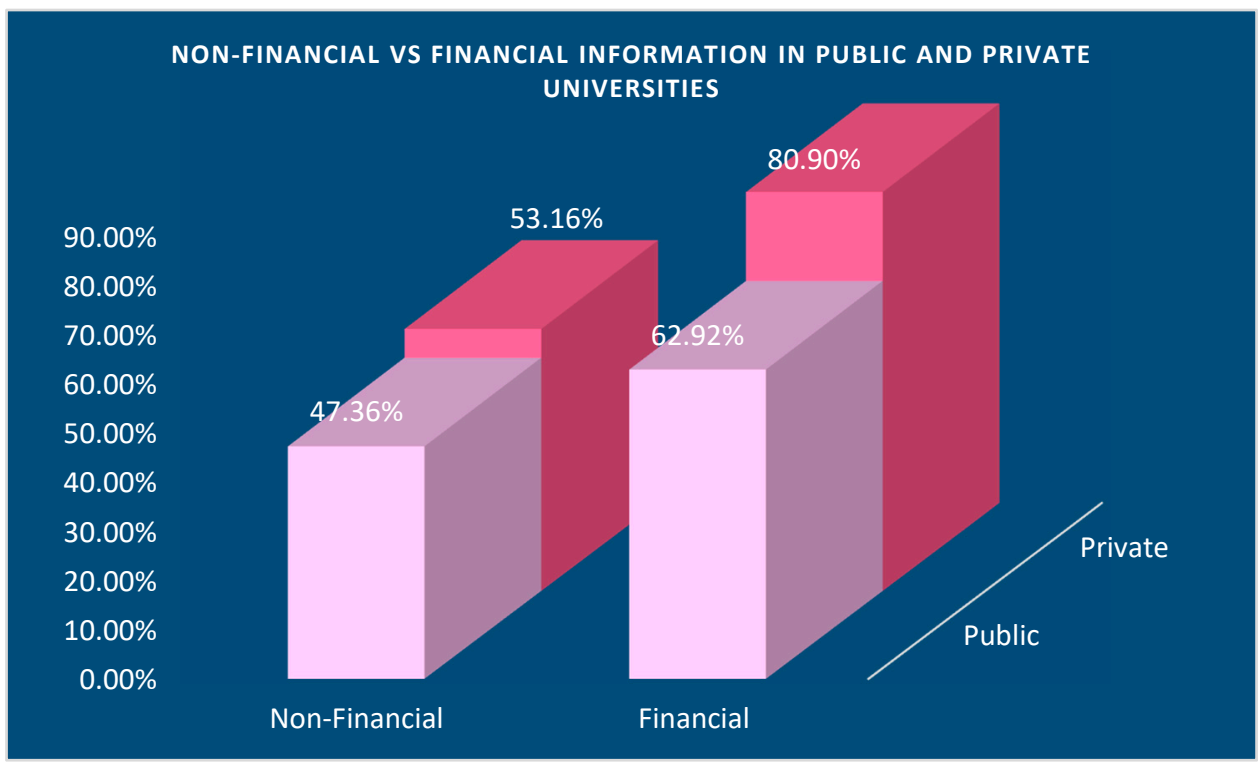

Figure 2. Comparative data in public and private universities. Source: Own compilation.

Delving further into public universities, it should be noted that two universities (Oxford University and Monash University) obtained the highest values (0.789) in non-financial information disclosure. For its part, Peking University (0.000) was less involved with this type of transparency.

With respect to financial information, it was found that the following entities were implementing transparency practices focused on financial information (0.909): University of Cambridge; University of California, Berkeley; University of Oxford; University of Washington; University College London; Swiss Federal Institute of Technology Zurich; University of Toronto; Imperial College London; University of Michigan-Ann Arbor; University of Copenhagen; University of Edinburgh; University of Manchester; University of Minnesota-Twin Cities; University of Melbourne; University of Colorado at Boulder; University of Illinois at Urbana-Champaign; University of British Columbia; University of Texas Southwestern Medical Center at Dallas; University of Maryland; College Park; King's College London; University of Bristol; and Swiss Federal Institute of Technology Lausanne. In addition, it can be mentioned that the universities of Oxford, Washington, and Manchester are the ones that strive more to make both types of information available to their stakeholders. In contrast, 11 universities barely disclosed financial information (0.091): University of Texas at Austin; University of Paris-Sud; Heidelberg University; Technical University Munich; Utrecht University; University of Zurich; Peking University; Ghent University; École Normale Superieure-Paris; University of Groningen; and Technion-Israel Institute of Technology.

Regarding private universities, Columbia University had the most applications for non-financial information release (0.842). If the minimum value is considered (0.263), Stanford University showed less transparency toward non-financial information.

Finally, the analysis of financial information highlights that Duke University $(0.100)$ was absolutely transparent in this respect, while Johns Hopkins University failed (0.091) at implementing this transparency initiative.

\subsection{Explanatory Analysis}

Concerning the second research question, the analysis of the influencing specific factors on the level of online engagement in the sampled universities was then performed. The scatterplot of the standardized residuals against standardized predicted values was checked once so that the point cloud did not follow any pattern, and the multiple linear regression was carried out, supposing linear relationships between variables [111,112]. The previous assumption was also confirmed by Fisher's critical value $(\mathrm{F}=5.823$; Statistical Signicicance $=0.000)$, allowing for the assumption of the 
existence of a significant linear relationship between the dependent variable and all of the independent variables [111,112]. In addition, after confirming the rest of the previous hypothesis (normality, homoscedasticity, independence, and collinearity) of the aforementioned methodological approach, a Pearson correlation analysis was conducted. This test revealed significant correlations between the independent variables "Funding", "Size", "Non-Financial", and "Financial" information (see Table 5). Despite the correlations found, the value detected was lower than 0.8 in all cases, so in line with Neter et al. [113], there were no potential multi-collinearity problems, and thus all the variables proposed remained in the model.

Table 5. Pearson correlation matrix.

\begin{tabular}{cccccc}
\hline Variables & FUND & SIZE & NFI & FI & REP \\
\hline FUND & 1 & & & & \\
SIZE & $-0.540^{* * *}$ & 1 & & & \\
NFI & $-0.366^{* * *}$ & $0.289^{* * *}$ & 1 & & \\
FI & $0.233^{* *}$ & -0.086 & -0.171 & 1 & \\
REP & -0.014 & 0.060 & -0.034 & 0.085 & 1 \\
\hline
\end{tabular}

Notes: ${ }^{* * *} p<0.01 ; * * p<0.05$. Source: Own compilation.

According to the conducted analysis, "Engagement" can be explained in 33.1\% by the considered model. If the inclusion of non-significant explanatory variables is considered, the goodness of the adjustment decreases to $26 \%$ (Table 6 ).

Table 6. Regression results.

\begin{tabular}{|c|c|c|c|c|c|}
\hline \multirow{2}{*}{ Hypothesis } & \multirow{2}{*}{ Model } & \multicolumn{2}{|c|}{ Unstandardized Coefficients } & \multirow{2}{*}{$\frac{\text { Standardized Coefficients }}{\text { Beta }}$} & \multirow{2}{*}{$\mathbf{t}$} \\
\hline & & B & Std. Error & & \\
\hline & (Constant) & 2.639 & 0.700 & & $3.771 * * *$ \\
\hline H1 & FUND & 0.630 & 0.266 & 0.308 & $2.370 * *$ \\
\hline $\mathrm{H} 2$ & SIZE & 0.008 & 0.002 & 0.450 & $3.617^{* * *}$ \\
\hline H3 & NFI & -0.019 & 0.287 & -0.007 & -0.066 \\
\hline $\mathrm{H} 4$ & FI & 0.290 & 0.113 & 0.276 & $2.564^{* *}$ \\
\hline \multirow[t]{3}{*}{ H5 } & REP & 0.086 & 0.040 & 0.223 & $2.135^{* *}$ \\
\hline & & & $\mathbf{R}$ & $\mathbf{R}^{2}$ & Adjusted $R^{2}$ \\
\hline & & & $56 \%$ & $33.1 \%$ & $26 \%$ \\
\hline
\end{tabular}

Notes: ${ }^{* * *} p<0.01 ; * * p<0.05 ; * p<0.1$. Source: Own compilation.

As for the typified regression coefficients, which help to value the relative importance of each independent variable in the equation, the results can be expressed:

$$
\mathrm{ENG}_{\mathrm{i}}=2.639+0.630 \cdot \mathrm{FUND}_{\mathrm{i}}+0.008 \cdot \mathrm{SIZE}_{\mathrm{i}}+(-0.019) \cdot \mathrm{NFI}_{\mathrm{i}}+0.290 \cdot \mathrm{FI}_{\mathrm{i}}+0.086 \cdot \mathrm{REP}_{\mathrm{i}} \text {, }
$$

In terms of significance, four of the five independent factors were found to be significant in the model. With reference to $H 1$, the results confirmed that private universities reached higher levels of stakeholder engagement through their social media than public universities $(\beta=0.308 ; p<0.05$ ). These findings were in line with the previous literature $[77,78]$, showing that entities operating with private funds were the most likely to implement the advantages of innovative technologies in order to communicate and strengthen links with their stakeholders. Moreover, due to their funding dependence on different donors, private universities need to meet the expectations of different groups involved in the community [70].

Analyzing H2, "Size" was statistically significant $(\beta=0.450 ; p<0.01)$ and thus, those universities with a higher number of students enrolled were more willing to establish different communication and participation strategies in order to enhance public online engagement. Therefore, while Galán-Valdivieso et al. [85] found a negative influence of size on more active stakeholder participation, the outcomes of this paper were in accordance with Haro et al. [28], who showed evidence of the positive effect of this factor on 
greater online engagement. A possible explanation relies on their greater exposure to public scrutiny, which leads to more attention, and in turn, reactions to information published in their social media. Likewise, as students are a collective who are very keen on using social media [114,115], there is a greater probability of obtaining significant interactions in the social media of universities. Therefore, the larger the student population, the greater the need for interactions.

Concerning organizational transparency, on one hand, the proposed model does not support H3 ( $\beta=-0.007 ; p>0.1)$. It seems that universities do not consider "Non-Financial Information" as a fundamental aspect to respond to increasing transparency demands and thus obtain greater involvement of their stakeholders. On the other hand, with regard to "Financial Information" (H4), the established hypothesis was supported $(\beta=0.276 ; p<0.05)$, that is, stakeholders react more to this transparency and, therefore, universities still prefer financial disclosure to improve accountability, increasing the commitment of the users of their social media.

The results related with non-financial openness in this case are contrary to Reilly and Hynan [116] and Fasan and Mio [117], who pointed out that non-financial information is a powerful engagement tool. In line with Constantinides and Zinck Stagno [118], the reason for this result could be that stakeholders perceive social media as a secondary communication channel when they already have their informative needs met via the universities' websites.

As for financial information, the findings differed from those obtained by Galán-Valdivieso et al. [85] and Dunne et al. [119], indicating that profitability data do not create higher levels of stakeholder commitment. In general terms, these results are shared by similar studies $[8,29]$, indicating that the increase in information disclosure of the organization fosters stakeholder engagement with the social media of the organization.

Finally, significant statistical results were found in relation to $\mathrm{H} 5(\beta=0.223 ; p<0.05)$. The reputation of the university has a direct influence on the participation of the public in social media channels. Particularly, the citations in Google Scholar boost the interest and engagement levels of the different stakeholder groups. This is in accordance with previous studies, which point out that reputation and stakeholder engagement are the aspects of organizational management that feedback to each other [91,92]. In addition, it seems that research outcomes, as prestige indicators, motivate and create interest in the community where the university is carrying out its mission $[93,96]$.

\section{Conclusions}

Previous studies have highlighted the importance of non-financial information for the appropriate fulfillment of organizational legitimacy and accountability in the private sector $[15,117]$ and in the public sphere [3,4], in order to strengthen stakeholder confidence and boost their engagement. This research highlights that universities fall behind in the disclosure of non-financial information versus financial information. However the data show that efforts are being made in this regard. In addition, it could be observed that universities are still disclosing more general organizational information instead of focusing on more specific aspects, for example, the information on management and quality obtained the lowest score. Moreover, if the differences between public and private sectors are considered, it has been found that private universities are the most committed to exploiting the advantages of web pages as a means for improving their legitimacy, spreading more key issues of financial information. As mentioned in the literature review, this may be due to the fact that the legislation regarding the disclosure of information for decision-making was previously implemented in the private sector. Therefore, these organizations have been making efforts along this line for longer, while these initiatives in the public sector are in their infancy.

By analyzing the best-ranked universities, this study also provides further progress in the results obtained in previous research on stakeholder online engagement motivations developed in another specific context $[28,85,91,116]$. Four significant drivers were found, which could increase stakeholder participation in social media. 
In particular, the explanatory findings stand out that private universities are more prominent in managing their social media and, therefore, the effective communication and participation strategies saw improvement in stakeholder engagement. Likewise, those with a greater size, which are the most exposed to public scrutiny, are the most willing to use this mechanism as a channel for rendering accounts and improving relations with their key stakeholders through open dialogue. In addition, the financial data seem to meet the expectations of the stakeholders, leading to greater interactions in social media. This result is not surprising, since financial issues have always aroused much public interest, especially after the last economic crisis. Finally, the expected results in relation to reputation were confirmed: those best-ranked universities are more exposed to the media, offering constant news about their research outcomes, thus generating more activity in their social media. These results can be explained under the legitimacy theory lens, highlighting that organizations are interested in using mechanisms that help them to obtain social approval on their intentions and decisions as well as stakeholder theory, which points out that organizations try to reinforce such legitimacy by considering all stakeholders in the fulfillment of their objectives.

This study seeks to contribute to the existing literature on the informational disclosure state, particularly in the higher education sector. Moreover, progress is being made in the knowledge of the situation of non-financial versus financial information in public and private universities. Likewise, the influence of both non-financial and financial transparency on stakeholder engagement was analyzed. In this sense, the scarce existing literature that analyzes the influencing factors of social engagement in university social media can be complemented.

From a practical point of view, the findings highlight that universities need greater adjustments in management efficiency, therefore they have to promote transparency toward non-financial information. In this sense, this could provide them with the benefits of legitimacy and greater commitment from their stakeholders. Additionally, the results present relevant information for university managers about the trends in the sector and as a benchmarking technique, mainly to help in the analysis of their position on transparency issues and consequently identify possible improvements. Although private, larger, and better positioned universities with greater visibility achieve higher levels of participation by their stakeholders, they should not neglect the growing demands of non-financial performance reporting. Likewise, public and smaller low-ranked universities should place greater value on the advantages that non-financial reporting provide as a legitimacy tool for greater stakeholder engagement.

Although this study presents valuable findings, it is not without limitations, which provide directions for further research. In this regard, the lack of data led to a relatively small sample, which could be expanded in future research. In addition, it would be interesting to analyze other contexts outside Europe and the U.S. including (or focusing on) countries such as Japan, Australia, or New Zealand. Examining new accountability mechanisms and their application as well as stakeholder engagement models through different social media could also be important to explore. In this regard, it would be useful to use participatory approaches in social sciences such as fuzzy cognitive maps. This approach can help evaluate and select a more effective communication model in the university sector.

Furthermore, as for the explanatory factors, these have been limited and generalized. It would be of great interest to expand both the internal and external, and in particular, more specific to the sector of higher education.

Author Contributions: Conceptualization, L.S.-S.; Data curation, L.S.-S.; Investigation, F.G.-V. and J.A.-C.; Methodology, L.S.-S.; Project administration, J.A.-C. and C.C.-P.; Supervision, C.C.-P.; Validation, C.C.-P. and F.G.-V.; Writing-Original draft, L.S.-S., J.A.-C. and F.G.-V. All authors have read and agreed to the published version of the manuscript.

Funding: This research was funded by the PAIDI group "NEW APPROACHES IN FINANCE AND BUSINESS INFORMATION SYSTEMS (SEJ385)" of the Andalusia government, Spain.

Conflicts of Interest: The authors declare no conflicts of interest. 


\section{References}

1. Coy, D.; Fischer, M.; Gordon, T. Public accountability: A new paradigm for college and university annual reports. Crit. Perspect. Accnt. 2001, 12,1-31. [CrossRef]

2. Newberry, S. Public sector accounting: Shifting concepts of accountability. Public Money Manag. 2015, 5, 371-376. [CrossRef]

3. Biondi, L.; Bracci, E. Sustainability, Popular and Integrated Reporting in the Public Sector: A Fad and Fashion Perspective. Sustainability 2018, 10, 3112. [CrossRef]

4. Montesinos, V.; Brusca, I. Non-financial reporting in the public sector: Alternatives, trends and opportunities. Span. Account. Rev. 2019, 22, 122-128. [CrossRef]

5. Flores, F.; Lizcano, J.L.; Mora, M.; Rejón, M. Información Integrada: Propuesta de un modelo. Rev. AECA 2012, 100, 32-36.

6. Warren, A.M.; Sulaiman, A.; Jaafar, N.I. Social media effects on fostering online civic engagement and building citizen trust and trust in institutions. Gov. Inf. Q. 2014, 31, 291-301. [CrossRef]

7. Sashi, C.M. Customer engagement, buyer-seller relationships, and social media. Manag. Decis. 2012, 50, 253-272. [CrossRef]

8. Taylor, M.; Kent, M.L. Dialogic Engagement: Clarifying Foundational Concepts. J. Public Relat. Res. 2014, 26, 384-398. [CrossRef]

9. Adams, C.A.; McNicholas, P. Making a Difference: Sustainability Reporting, Accountability and Organisational Change. Account. Audit. Account. J. 2007, 20, 382-402. [CrossRef]

10. Michelon, G. Sustainability disclosure and reputation: A comparative study. Corp. Reput. Rev. 2011, 14, 79-96. [CrossRef]

11. Garde, R. Revelación Online de Información Sobre Responsabilidad Social Universitaria: Propuesta de un Modelo e Incentivos de Divulgación. Ph.D. Thesis, University of Granada, Granada, Spain, 2013.

12. Larrán-Jorge, M.; Andrades-Peña, F.J. Análisis de la responsabilidad social universitaria desde diferentes enfoques teóricos. Rev. Iberoam. Educ. Sup. 2015, 6, 91-107.

13. Carini, C.; Rocca, L.; Veneziani, M.; Teodori, C. Ex-ante impact assessment of sustainability information-the directive 2014/95. Sustainability 2018, 10, 560. [CrossRef]

14. Manes-Rossi, F.; Tiron-Tudor, A.; Nicolò, G.; Zanellato, G. Ensuring more sustainable reporting in Europe using non-financial disclosure-de facto and de jure evidence. Sustainability 2018, 10, 1162. [CrossRef]

15. Arvidsson, S. Disclosure of non-financial information in the annual report: A management-team perspective. J. Intellect. Cap. 2011, 12, 277-300. [CrossRef]

16. Dima, B.; Cuzman, I.; Şărămăt, O. Effects of financial and non-financial information disclosure on prices' mechanisms for emergent markets: The case of Romanian Bucharest Stock Exchange. Account. Manag. Inf. Syst. 2013, 12, 76 .

17. Dumay, J.; Frost, G.; Beck, C. Material legitimacy: Blending organisational and stakeholder concerns through non-financial information disclosures. J. Account. Org. Chang. 2015, 11, 2-23. [CrossRef]

18. Brusca, I.; Labrador, M.; Larran, M. The challenge of sustainability and integrated reporting at universities: A case study. J. Clean. Prod. 2018, 188, 347-354. [CrossRef]

19. Gamage, P.; Sciulli, N. Sustainability reporting by Australian universities. Aust. J. Public Adm. 2017, 76, 187-203. [CrossRef]

20. Siboni, B.; del Sordo, C.; Pazzi, S. Sustainability reporting in state universities: An investigation of Italian pioneering practices. Int. J. Soc. Ecol. Sustain. Dev. 2013, 4, 1-15. [CrossRef]

21. Sassen, R.; Azizi, L. Voluntary disclosure of sustainability reports by Canadian universities. J. Bus. Econ. 2018, 88, 97-137. [CrossRef]

22. Ndou, V.; Secundo, G.; Dumay, J.; Gjevori, E. Understanding intellectual capital disclosure in online media Big Data: An exploratory case study in a university. Medit. Account. Res. 2018, 26, 499-530. [CrossRef]

23. Ramírez, Y.; Tejada, Á.; Baidez, A. Intellectual Capital and Transparency in Universities: An Empirical Study. Int. Sch. Sci. Res. Innov. 2015, 9, 9.

24. Romenti, S. Reputation and stakeholder engagement: An Italian case study. J. Commu. Manag. 2010, 14, 306-318. [CrossRef]

25. Pletikosa Cvijikj, I.; Michahelles, F. Online Engagement Factors on Facebook brand pages. Soc. Netw. Anal. Min. 2013, 3, 843-861. [CrossRef] 
26. Bonsón, E.; Royo, S.; Ratkai, M. Facebook Practices in Western European Municipalities: An Empirical Analysis of Activity and Citizens' Engagement. Adm. Soc. 2017, 49, 320-347. [CrossRef]

27. Sáez-Martín, A.; Haro-de-Rosario, A.; Caba-Pérez, M.C. Using twitter for dialogic communication: Local government strategies in the European Union. Local Gov. Stud. 2015, 41, 421-444. [CrossRef]

28. Haro-de-Rosario, A.; Sáez-Martin, A.; Caba-Pérez, M.C. The use of Facebook to promote engagement with local governments in Spain. In Social Media and Local Governments; Springer: Cham, Switzerland, 2016; pp. 219-241.

29. Haro-de-Rosario, A.; Sáez-Martin, A.; Caba-Pérez, M.C. Using social media to enhance citizen engagement with local government: Twitter or Facebook? New Media Soc. 2018, 20, 29-49. [CrossRef]

30. Benneworth, P. University Engagement with Socially Excluded Communities; Springer: Enschede, The Netherlands, 2013.

31. De Aguilera-Moyano, M.; Farias-Batlle, P.; Baraybar-Fernández, A. La comunicación universitaria: Modelos, tendencias y herramientas para una nueva relación con sus públicos. Rev. ICONO 14 2010, 8, 90-124. [CrossRef]

32. Ojino, R.; Mich, L.; Ogao, P.; Karume, S. The Quality of Kenyan University Web pages: A Study for the Re-engineering of the Masinde Muliro University Web page. J. e-Learn. Knowl. Soc. 2013, 9, 169-176.

33. Kim, D.; Chun, H.; Kwak, Y.; Nam, Y. The employment of dialogic principles in website, Facebook, and Twitter platforms of environmental nonprofit organizations. Soc. Sci. Comput. Rev. 2014, 32, 590-605. [CrossRef]

34. European Commission. Directive 2014/95/EU of the European Parliament and the Council of 22 October 2014 amending Directive 2013/34/EU as regards disclosure of non-financial and diversity information by certain large undertakings and groups. ABlEU L 2014, 330, 1-9.

35. Ioannou, I.; Serafeim, G. The Consequences of Mandatory Corporate Sustainability Reporting. Harvard Business School Research Working Paper 2017, no 11-100. Available online: https:/papers.ssrn.com/soL3/ papers.cfm?abstract_id=1799589 (accessed on 5 November 2019).

36. Jeffery, C. Comparing the Implementation of the EU Non-Financial Reporting Directive in the UK, Germany, France and Italy. Frank Bold. 2017. Available online: https://ssrn.com/abstract $=3083368$ (accessed on 5 November 2019).

37. Venturelli, A.; Caputo, F.; Leopizzi, R.; Pizzi, S. The state of art of corporate social disclosure before the introduction of non-financial reporting directive: A cross country analysis. Soc. Responsib. J. 2019, 15, 409-423. [CrossRef]

38. Sustainability Accounting Standards Board (SASB). SASB Legal Roundtable at Harvard Law School. 2017. Available online: https://www.sasb.org/knowledge-hub/sasb-legal-roundtable/ (accessed on 5 November 2019).

39. U.S. Chamber of Commerce Foundation. Corporate Sustainability Reporting: Past, Present, Future. 2018. Available online: https://www.uschamberfoundation.org/ (accessed on 8 October 2019).

40. Climate Disclosure Standards Board (CDSB). Corporate Reporting in the United States and Canada. 2017. Available online: https://www.reportingexchange.com/ (accessed on 15 September 2018).

41. Ajax, C.M.; Strauss, D. Corporate Sustainability Disclosures in American Case Law: Purposeful or Mere Puffery. Ecol. LQ 2018, 45, 703. [CrossRef]

42. NASDAQ. ESG Reporting Guide 2.0. 2019. Available online: https://www.nasdaq.com/docs/2019/11/26/2019ESG-Reporting-Guide.pdf (accessed on 8 October 2019).

43. Eccles, R.G.; Saltzman, D. Achieving sustainability through integrated reporting. Stanf. Soc. Innov. Rev. Summer 2011, 59, 56-61.

44. Noronha, C.; Tou, S.; Cynthia, M.I.; Guan, J.J. Corporate social responsibility reporting in China: An overview and comparison with major trends. Corp. Soc. Resp. Environ. Manag. 2013, 20, 29-42. [CrossRef]

45. Jacobs, K. Theorising Interdisciplinary Public Sector Accounting Research. Financ. Account. Manag. 2016, 32, 469-488. [CrossRef]

46. Liguori, M.; Sicilia, M.; Steccolini, I. Some like it non-financial ... Politicians' and managers' views on the importance of performance information. Public Manag. Rev. 2012, 14, 903-922. [CrossRef]

47. Katsikas, E.; Manes Rossi, F.; Orelli, R. Towards Integrated Reporting. In Accounting Change in the Public Sector; Springer International Publishing: London, UK, 2017.

48. Milne, M.J.; Gray, R. W(h)ither ecology? The triple bottom line, the global reporting initiative, and corporate sustainability reporting. J. Bus. Ethics 2013, 118, 13-29. [CrossRef] 
49. Szabó, D.G.; Sørensen, K.E. New EU Directive on the Disclosure of Non-Financial Information (CSR). Nordic \& European Company Law Working Paper 2015, 15-01. Available online: https://papers.ssrn.com/sol3/ papers.cfm?abstract_id=2606557 (accessed on 5 November 2019).

50. Orens, R.; Aerts, W.; Cormier, D. Web-based non-financial disclosure and cost of finance. J. Bus. Financ. Account. 2010, 37, 1057-1093. [CrossRef]

51. Daske, H.; Gebhardt, G. International financial reporting standards and experts' perceptions of disclosure quality. Abacus 2006, 42, 461-498. [CrossRef]

52. Tontiset, N.; Kaiwinit, S. The Factors Affecting Financial Reporting Reliability: An Empirical Research of Public Listed Companies in Thailand. J. Mod. Account. Audit. 2018, 14, 291-304.

53. Nogueira, S.P.S.; Jorge, S.M.F. Explanatory factors for the use of the financial report in decision-making: Evidence from Local Government in Portugal. Rev. Contab. 2016, 19, 216-226. [CrossRef]

54. Brusca, I. Thirty years of research in public sector accounting and management in Spain. Span. Account. Rev. 2010, 13, 175-209.

55. Bartolacci, F.; Paolini, A.; Quaranta, A.G.; Soverchia, M. Assessing factors that influence waste management financial sustainability. Waste Manag. 2018, 79, 571-579. [CrossRef] [PubMed]

56. Wang, Y.; Zhi, Q. The role of green finance in environmental protection: Two aspects of market mechanism and policies. Energy Procedia 2016, 104, 311-316. [CrossRef]

57. Falcone, P.M. Green investment strategies and bank-firm relationship: A firm-level analysis. Econ. Bull 2018, 38, 2225-2239.

58. Falcone, P.M.; Sica, E. Assessing the opportunities and challenges of green finance in Italy: An analysis of the biomass production sector. Sustainability 2019, 11, 517. [CrossRef]

59. Gallego-Álvarez, I.; Rodríguez-Domínguez, L.; García-Sánchez I-M. Information disclosed online by Spanish universities: Content and explanatory factors. Online Inf. Rev. 2011, 35, 360-385. [CrossRef]

60. Kaya, T.; Erkut, B. Tacit Knowledge Capacity: A Comparison of University Lecturers in Germany and North Cyprus. Electron. J. Knowl. Manag. 2018, 16, 131-142.

61. Secundo, G.; Dumay, J.; Schiuma, G.; Passiante, G. Managing intellectual capital through a collective intelligence approach: An integrated framework for universities. J. Intellect. Cap. 2016, 17, 298-319. [CrossRef]

62. Secundo, G.; Perez, S.E.; Martinaitis, Z.; Leitner, K.H. An intellectual capital maturity model (ICMM) to improve strategic management in European universities: A dynamic approach. J. Intellect. Cap. 2015, 16, 419-442. [CrossRef]

63. Guthrie, G.; Dumay, J. New frontiers in the use of intellectual capital in the public sector. J. Intellect. Cap. 2015, 16, 258-266. [CrossRef]

64. Ramirez, Y.; Gordillo, S. Recognition and measurement of intellectual capital in Spanish universities. J. Intellect. Cap. 2014, 15, 173-188. [CrossRef]

65. Zeng, X.D.; Xu, X.D.; Yin, T.H.; Tam, C.M. Factors that Drive Chinese Listed Companies in Voluntary Disclosure of Environmental Information. J. Bus. Ethics 2012, 109, 309-321. [CrossRef]

66. Reverte, C. Determinants of corporate social responsibility disclosure ratings by Spanish listed firms. J. Bus. Ethics 2009, 88, 351-366. [CrossRef]

67. Bonsón, E.; Ratkai, M. A set of metrics to assess stakeholder engagement and social legitimacy on a corporate Facebook page. Online Inf. Rev. 2013, 37, 787-803. [CrossRef]

68. Freeman, R.E. Strategic Management: A Stakeholder Approach; Pitman Press: Boston, MA, USA, 1984.

69. Suchman, M.C. Managing Legitimacy: Strategic and Institutional Approaches. Acad. Manag. Rev. 1995, 20, 571-610. [CrossRef]

70. Cuadrado-Ballesteros, B.; Frías-Aceituno, J.; Martínez-Ferrero, J. The role of media pressure on the disclosure of sustainability information by local governments. Online Inf. Rev. 2014, 38, 114-135. [CrossRef]

71. Serrano-Cinca, C.; Rueda-Tomás, M.; Portillo-Tarragona, P. Factors influencing e-disclosure in local public administrations. Environ. Plan. C Gov. Policy 2009, 27, 355-378. [CrossRef]

72. Men, L.R. CEO Credibility, perceived organizational reputation, and employee engagement. Pub. Relat. Rev. 2012, 38, 171-173. [CrossRef]

73. Bonsón, E. and Flores, F. Social media and corporate dialogue: The response of global financial institutions. Online Inf. Rev. 2011, 35, 34-49. [CrossRef]

74. Sáez-Martin, A.; Haro-de-Rosario, A.; Caba-Pérez, M.D.C. A vision of social media in the Spanish smartest cities. Transf. Gov. People Proc. Policy 2014, 8, 521-544. [CrossRef] 
75. Agostino, D. Using social media to engage citizens: A study of Italian municipalities. Pub. Relat. Rev. 2013, 39, 232-234. [CrossRef]

76. Bellucci, M.; Biagi, S.; Manetti, G. Dialogic Accounting and Stakeholder Engagement through Social Media: The Case of Top-Ranked Universities. Rev. High. Educ. 2019, 42, 1145-1184. [CrossRef]

77. Brunner, J.J. La universidad: ¿comunidad de mercado o posmoderna? Bordón. Rev. de Pedagogía 2012, 64, 27-38.

78. Patten, D.; Guidry, R. Market reactions to the first-time issuance of corporate sustainability reports: Evidence that quality matters. Sustain. Account. Manag. Policy J. 2010, 1, 33-50.

79. Hofmann, S.; Beverungen, D.; Räckers, M.; Becker, J. What makes local governments' online communications successful? Insights from a multi-method analysis of Facebook. Gov. Inf. Q. 2013, 30, 387-396. [CrossRef]

80. Picazo, S.; Gutiérrez, I.; Luna, L.F. Understanding risks, benefits, and strategic alternatives of social media applications in the public sector. Gov. Inf. Q. 2012, 29, 504-511. [CrossRef]

81. Surroca, J.; Tribó, J.A. Managerial Entrenchment and Corporate Social Performance. J. Bus. Financ. Account. 2008, 35, 748-789. [CrossRef]

82. Snead, J.T. Social media use in the U.S. Executive branch. Gov. Inf. Q. 2013, 30, 56-63. [CrossRef]

83. Ackerman, J.M.; Sandoval-Ballesteros, I.E. The global explosion of freedom of information laws. Adm. Law Rev. 2006, 58, 85-130.

84. Eccles, R.G.; Krzus, M.P.; Watson, L.A. Integrated Reporting Requires Integrated Assurance. In Effective Auditing for Corporates: Key Developments in Practice and Procedures; Oringel, J., Ed.; Bloomsbury Information Ltd.: London, UK, 2012; pp. 161-178.

85. Galán-Valdivieso, F.; Saraite-Sariene, L.; Alonso-Cañadas, J.; Caba-Pérez, M.D.C. Do Corporate Carbon Policies Enhance Legitimacy? A Social Media Perspective. Sustainability 2019, 11, 1161. [CrossRef]

86. De la Torre, R.; Torres, E. Transparencia y buen gobierno en la universidad pública. Reflexiones en torno al caso mexicano. Rev. Online Espec. Derecho Comun. 2010, 4, 1-13.

87. Cerrillo-i-Martínez, A. La contribución de las TIC a la mejora de la transparencia administrativa. Arbor 2012, 188, 707-724. [CrossRef]

88. Mergel, I. Social media adoption and resulting tactics in the US federal government. Gov. Inf. Q. 2013, 30, 123-130. [CrossRef]

89. Mainka, A.; Hartmann, S.; Stock, W.G.; Peters, I. Government and social media: A case study of 31 informational world Cities. In Proceedings of the 47th Hawaii International Conference on System Sciences, Waikoloa, HI, USA, 6-9 January 2014; IEEE: New York, NY, USA, 2014; pp. 1715-1724.

90. Donaldson, T.; Preston, L.E. The stakeholder theory of the corporation: Concepts, evidence and implications. Acad. Manag. Rev. 1995, 20, 65-91. [CrossRef]

91. Dijkmans, C.; Kerkhof, P.; Beukeboom, C.J. A stage to engage: Social media use and corporate reputation. Tour. Manag. 2015, 47, 58-67. [CrossRef]

92. Hollebeek, L.D. Demystifying customer brand engagement: Exploring the loyalty nexus. J. Mark. Manag. 2011, 27, 785-807. [CrossRef]

93. Flórez, J.M.; López, M.V.; López, A.M. Transparency and its determinants at Colombian universities. High. Educ. Res. Dev. 2017, 36, 674-687. [CrossRef]

94. Leydesdorff, L.; Shin, J. How to evaluate universities in terms of their relative citation impacts: Fractional counting of citations and the normalization of differences among discipline. J. Am. Soc. Inf. Sci. Tech. 2011, 62, 1146-1155. [CrossRef]

95. Ferrer, J.; Morris, L. Engaging élitism: The mediating effect of work engagement on affective commitment and quit intentions in two Australian University Groups. High. Educ. Q. 2013, 67, 340-357. [CrossRef]

96. Hazelkorn, E. Learning to live with league tables and ranking: The experience of institutional leaders. High. Educ. Policy 2008, 21, 193-215. [CrossRef]

97. Saraite-Sariene, L.; Haro-de-Rosario, A.; Gálvez-Rodríguez, M.M.; Caba-Pérez, M.D.C. Exploring Determining Factors of Web Transparency in the World's Top Universities. Span. Account. Rev. 2018, 21, 63-72. [CrossRef]

98. Flórez-Parra, J.; López-Pérez, M.V.; López-Hernández, A.M. Corporate governance, analysis of the top 100 universities in the Shanghai ranking. Rev. Educ. 2014, 364, 170-196.

99. Rodríguez-Bolívar, M.P.; Garde-Sánchez, R.; López-Hernández, A.M. Online disclosure of corporate social responsibility information in leading Anglo-American Universities. J. Environ. Policy Plan. 2013, 15, 515-575. [CrossRef] 
100. Lodhia, S.K.; Allam, A.; Lymer, A. Corporate Reporting on the Internet in Australia: An Exploratory Study. Aust. Account. Rev. 2004, 14, 64-71. [CrossRef]

101. Escobar, B. Análisis empírico de la Responsabilidad social universitaria en Andalucía. Encuentros. Multidiscip. 2016, 18, 1-14.

102. McDaniel, L.; Martin, R.D.; Maines, L.A. Evaluating Financial Reporting Quality: The Effects of Financial Expertise vs. Financial Literacy. Account. Rev. 2002, 77, 139-167. [CrossRef]

103. Uwalomwa, U.; Marte Uadiale, O. Corporate social and environmental disclosure in Nigeria: A comparative study of the building material and brewery industry. Int. J. Bus. Manag. 2011, 6, 258-264. [CrossRef]

104. Garde-Sánchez, R.; Rodríguez-Bolívar, M.P.; López-Hernández, A.M. Online disclosure of university social responsibility: A comparative study of public and private US universities. Environ. Educ. Res. 2013, 19, 709-746. [CrossRef]

105. Gartchie-Gatsi, J.; Gameli-Gadzo, S. Introduction to Quantitative Methods in Business; Xlibris Corporation: London, UK, 2016.

106. Garde-Sánchez, R.G.; Rodríguez-Bolívar, M.P.R.; López-Hernández, A.M.L. Corporate and managerial characteristics as drivers of social responsibility disclosure by state-owned enterprises. Rev. Manag. Sci. 2017, 11, 633-659. [CrossRef]

107. Jabnoun, N. The influence of wealth, transparency, and democracy on the number of top ranked universities. Q. Assur. Educ. 2015, 23, 108-122. [CrossRef]

108. Alma, B.; Coşkun, E.; Övendireli, E. University Ranking Systems and Proposal of a Theoretical Framework for Ranking of Turkish Universities: A Case of Management Departments. Procedia-Soc. Behav. Sci. 2016, 235, 128-138. [CrossRef]

109. Arzberger, P.; Schroeder, P.; Beaulieu, A.; Bowker, G.; Casey, K.; Laaksonen, L.; Wouters, P. Promoting access to public research data for scientific, economic, and social development. Data Sci. J. 2004, 3, 135-152. [CrossRef]

110. Kim, Y.; Adler, M. Social scientists' data sharing behaviors: Investigating the roles of individual motivations, institutional pressures, and data repositories. Int. J. Inf. Manag. 2015, 35, 408-418. [CrossRef]

111. Hair, J.F.; Anderson, R.E.; Tatham, R.L.; Black, W.C. Análisis Multivariante, 5th ed.; Prentice Hall: Upper Saddle River, NJ, USA, 1999.

112. Rawlings, J.O.; Pantula, S.G.; Dickey, D.A. Applied Regression Analysis: A Research Tool; Springer Science \& Business Media: New York, NY, USA, 2001.

113. Neter, J.; Kutner, M.H.; Nachtsheim, C.J.; Wasserman, W. Applied Linear Regression Models, 3rd ed.; McGraw-Hill Companies, Inc.: London, UK, 1996.

114. Davis III, C.H.; Deil-Amen, R.; Rios-Aguilar, C.; Canche, M.S.G. Social Media in Higher Education: A literature Review and Research Directions; The Center for the Study of Higher Education at the University of Arizona and Claremont Graduate University: Tucson, AZ, USA, 2012.

115. Sutherland, K.; Davis, C.; Terton, U.; Visser, I. University student social media use and its influence on offline engagement in higher educational communities. Stud. Success 2018, 9, 13-24. [CrossRef]

116. Reilly, A.H.; Hynan, K.A. Corporate communication, sustainability, and social media: It's not easy (really) being green. Bus. Horiz. 2014, 57, 747-758. [CrossRef]

117. Fasan, M.; Mio, C. Fostering stakeholder engagement: The role of materiality disclosure in integrated reporting. Bus. Strategy Environ. 2017, 26, 288-305. [CrossRef]

118. Constantinides, E.; Zinck Stagno, M.C. Potential of the social media as instruments of higher education marketing: A segmentation study. J. Mark. High. Educ. 2011, 21, 7-24. [CrossRef]

119. Dunne, T.; Helliar, C.; Lymer, A.; Mousa, R. Stakeholder engagement in internet financial reporting: The diffusion of XBRL in the UK. Br. Account. Rev. 2013, 45, 167-182. [CrossRef]

(C) 2019 by the authors. Licensee MDPI, Basel, Switzerland. This article is an open access article distributed under the terms and conditions of the Creative Commons Attribution (CC BY) license (http://creativecommons.org/licenses/by/4.0/). 